\title{
Prevalence of hopQ Alleles and Relationship between cagA and vacA s1 with hopQ I Gene in Helicobacter pylori Strains Isolated from Patients with Peptic Ulcer Referred to Towhid Hospital in Sanandaj (2014)
}

\author{
Amin Hooshyar Chichaklu ${ }^{1,2}$, Manouchehr Ahmadi Hedayati2,3*, \\ Farshad Sheykh Esmaili ${ }^{3}$, Ebrahim Ghaderi ${ }^{4}$ \\ and Mohammad Hossein Dareh Shiri, ${ }^{1,2}$ \\ ${ }^{1}$ Student Research Committee, Kurdistan University of Medical Sciences, Sanandaj, Iran \\ ${ }^{2}$ Department of Microbiology, Kurdistan University of Medical Sciences, Sanandaj, Iran \\ ${ }^{3}$ Liver and Digestive Research Center, Kurdistan University of Medical Sciences, Sanandaj, Iran \\ ${ }^{4}$ Department of Statistics and Epidemiology, Kurdistan University of Medical Sciences, Sanandaj, Iran \\ http://dx.doi.org/10.13005/bbra/2008
}

(Received: 10 January 2016; accepted: 20 February 2016)

\begin{abstract}
Infection with $H$. pylori leads to digestive diseases including gastritis, peptic ulcer, and gastric adenocarcinoma. The virulence factors of $\boldsymbol{H}$. pylori outer membrane proteins or Hop (Helicobacter pylori outer membrane protein) as an auto transporter and has widely adhesion properties, phase changes and recombination. $H$. pylori genome is widely encoded HopQ (Helicobacter pylori outer membrane protein Q), which affect the strains of $\mathrm{H}$. pylori binding to human epithelial cells. The aim of this study determine the prevalence of $h o p Q$ alleles and associated Between $\operatorname{cag} A$ and $v a c A s 1$ with $h o p Q I$ gene in $H$. pylori strains isolated from patients with peptic ulcer referred to Towhid Hospital in Sanandaj (2014). Biopsy specimens from 100 patients with peptic ulcer $H$. pylori positive were collected and separated, different allele hopQ, vacA, $\operatorname{cag} A$ by $\mathrm{PCR}$ (Polymerase Chain reaction) was determined. The relationship between genes, cag $A$ and vacA s1 hopQ I with Chi-square test SPSS version 20 (version 19, SPSS Inc., Chicago, IL) was used. $P$ value $<0.05$ was considered as significant. The frequency of genes hop $Q I$, hopQ II, cagA, vacA s1, vacA s2, respectively, 54 (54\%), 46 (46\%), $51(51 \%), 83(83 \%), 17$ (17\%). The relationship between hop $I$ and $\operatorname{cag} A(\mathrm{P}<0.01)$, hop $Q I$ and vacA sI $(\mathrm{P}<0.026)$, respectively. In this study, the presence of the CagA and hopQ I, HopQ I and VacA S1 gene in patients with gastric ulcer statistically significant relationship was found.
\end{abstract}

Keywords: Helicobacter pylori, HopQ, Peptic ulcer, outer membrane proteins, Sanandaj.

Helicobacter pylori are gram-negative bacteria that persistently colonize the human gastric mucosa. Gastric colonization by H. pylori is a risk factor for the development of peptic ulcer disease and distal gastric adenocarcinoma. When H. pylori isolates from unrelated humans are compared, a high level of genetic diversity is consistently detected Genetic diversity among $H$.

\footnotetext{
* To whom all correspondence should be addressed.

E-mail: hooshyar.kums@gmail.com
}

pylori strains helps to account for varying clinical outcomes among persons colonized with $H$. pylori Candidate markers for distinguishing diseaseassociated H. pylori strains (i.e., those associated with peptic ulceration or gastric adenocarcinoma) from less virulent strains include presence of the cag pathogenicity island and $\mathrm{s} 1 / \mathrm{m} 1$ polymorphisms in vacA alleles. High rates of Helicobacter pylori infection in Iran and increase the number of gastrointestinal complaints led to study whether the presence of the alleles can result in disease affects HopQ. The main objective of this study 
was to evaluate the association between the presence of CagA and VacA genes of H. pylori hopQ two major alleles with clinical samples isolated from patients with peptic ulcer using the PCR method.

\section{METHODANDMATERIALS}

Horoscopes have on patients over 18 years old with sadness in the area of the upper GI endoscopy Towhid Hospital affiliated to Kurdistan University of medical science were presented. Information on factors such as age, sex and drugs obtained by questionnaire and were prepared for all forms of morality with peptic ulcer patients. Pathological diagnosis or procedure was performed by a specialist. At least two biopsies from each patient to test RUT (Rapid urea test) and another sample to study the molecular and pathological study. Extracted DNA (Deoxyribonucleic acid) and PCR (Polymerase Chain reaction). To investigate the molecular sample taken after the transition to 1.5 microliter tubes containing thioglycollate medium in microbiology research lab data transfer Kurdistan University of Medical Sciences and the extraction time were stored in a freezer at $-80^{\circ} \mathrm{C}$. To extract DNA, biopsy samples on the slide was transferred in sterile conditions and carefully slide the other was crushed sterile. Then DNA extraction kit to help QIAamp DNA Mini Kit (QIAGEN) was performed. Specific primers for genes HopQ I / II, VacA and CagA in Table 1. The final volume of 25 $\mathrm{ml}$ and all the PCR using Master kit (Cinnagen, Iran). Thermal cycling for PCR amplification were optimized as shown in Table 2. Green PCR products by $2 \%$ agarose gel and stained with Sybeer green (Cinnagen, Iran) and review by UV (Ultraviolet) was observed. To search for an allele I (Table 3) CagA gene-gene and gene HopQ VacA s1 in patients with peptic ulcer associated and whether this difference was statistically significant? (Table 4), the chi-square test software SPSS-20 (version 20, SPSS Inc., Chicago, IL) was used. 0.05p < was considered as significant.

\section{RESULTS}

The study of 100 samples from patients with upper gastrointestinal disorders and in patients with $H$. pylori-positive peptic ulcer disease $94-93$ years were collected. The frequency of genes HopQ I, HopQ II, CagA, VacA S1, VacA S2, respectively, 54 (54\%), 46 (46\%), 51 (51\%), 83 (83\%), 17 (17 percent). A significant correlation between the

Table 1. Primer Designer

\begin{tabular}{|c|c|c|c|c|}
\hline $\begin{array}{l}\text { Gene or } \\
\text { locus }\end{array}$ & $\begin{array}{l}\text { Primer } \\
\text { designation }\end{array}$ & Primer 5' $\rightarrow 3^{\prime}$ & $\begin{array}{l}\text { Amplimer } \\
\text { size(bp) }\end{array}$ & reference \\
\hline HP1177 & $\begin{array}{l}\text { hopQ I F } \\
\mathrm{R}\end{array}$ & $\begin{array}{l}\text { ACGAACGCGCAAAAACTTTA } \\
\text { TTGCCATTCTCATCGGTGTA }\end{array}$ & 187 & [1] \\
\hline HP1177 & $\begin{array}{l}\text { hopQII F } \\
\mathrm{R}\end{array}$ & $\begin{array}{l}\text { ACAGCCACTCCAATCCAGAA } \\
\text { AACCCCACCGTGGATTTTAG }\end{array}$ & 160 & [1] \\
\hline $\operatorname{cag} \mathrm{A}$ & $\begin{array}{l}\text { cagAF } \\
\mathrm{R}\end{array}$ & $\begin{array}{l}\text { TTGACCAACAACCACAAACCGAAG } \\
\text { CTTCCCTTAATTGCGAGATTCC }\end{array}$ & 183 & {$[1]$} \\
\hline vacA & $\begin{array}{l}\text { VA1 F } \\
\text { V136 R }\end{array}$ & $\begin{array}{l}\text { ATGGAAATACAACAAACACAC } \\
\text { CAACAATGGCTGGAATGAT }\end{array}$ & 136 & [1] \\
\hline
\end{tabular}

Table 2. Program thermocycler instruments

\begin{tabular}{lc}
\hline $\begin{array}{l}\text { Steps of PCR technique } \\
35 \text { cycles of: }\end{array}$ & Temperature and time \\
\hline First denaturation & $95^{\circ}(15 \mathrm{~min})$ \\
Denaturation & $95^{\circ}(1 \mathrm{~min})$ \\
Annealing & $56^{\circ}(1 \mathrm{~min})$ \\
Extention & $72^{\circ}(65 \mathrm{sec})$ \\
Final extention & $72^{\circ}(5 \mathrm{~min})$ \\
\hline
\end{tabular}

presence of the gene HopQ I CagA $(0.01 \mathrm{P}<)$ and gene hopQ I VacA S1 $(0.026 \mathrm{P}<)$ and VacA S2 II HopQ with CagA-negative and statistically shown.

\section{DISCUSSION}

Progress by the interaction of several factors in the pathogenesis of $H$. pylori infection as well as infection by Helicobacter pylori host of 
Table 3. Frequency of hopQ, vacA and cagA Genotypes in Peptic ulcer patient

\begin{tabular}{llllll}
\hline & & \multicolumn{5}{c}{ Genotypes } \\
Allele & hopQI & hopQ II & vacA s1 & vacA s2 & cagA \\
\hline Positive & $\mathrm{n}^{*}=54(54 \%)$ & $\mathrm{n}=46(46)$ & $\mathrm{n}=83(83 \%)$ & $\mathrm{n}=17(17 \%)$ & $\mathrm{n}=51(51 \%)$ \\
Negative & $\mathrm{n}=46(46 \%)$ & $\mathrm{n}=54(54 \%)$ & $\mathrm{n}=17(17 \%)$ & $\mathrm{n}=83(83 \%)$ & $\mathrm{n}=49(49 \%)$ \\
\hline
\end{tabular}

$*(\mathrm{n}=100)$

Table 4. Relationship between hop $Q$ Alleles and $c a g A$ and $v a c A$

\begin{tabular}{lllll}
\hline \multirow{2}{*}{ Gene or Allele } & & \multicolumn{2}{c}{ hopQ } & \multirow{2}{*}{$\begin{array}{c}\text { Two-sided P* value } \\
\text { Pearson Chi-Square }\end{array}$} \\
\cline { 3 - 4 } & & hopQ I & hopQ II & \\
\hline \multirow{2}{*}{ cagA } & Positive & $34(66.7 \%)$ & $17(33.3 \%)$ & $<0.010$ \\
& Negative & $20(40.8 \%)$ & $29(59.2 \%)$ & \\
& s1 & $49(59.0 \%)$ & $34(41.0 \%)$ & $<0.026$ \\
& s2 & $5(29.4 \%)$ & $12(70.6 \%)$ & \\
\hline
\end{tabular}

${ }^{*} \mathrm{p}$ value of $<0.05$ was considered as statistically significant

superficial inflammation of the stomach and inevitable role in the etiology of peptic ulcer disease show $^{2,3}$. Access to the successful colonization of the biological concepts and long for a bacterial adhesion mechanism is complex. The bacterial produced the largest share among all products should be made to account for bacterial colonization $^{4}$. HopQ gene in the bacterium Helicobacter pylori is a major protein of the outer membrane of $H$. pylori DNA is the largest family of proteins. To determine the relationship between HopQ and gastrointestinal diseases may be a point to answer questions about the adhesion of the bacteria to the stomach cells to provide. The study to determine the frequency of genotypes associated HopQ and HopQ I CagA gene and hopQ I VacA S1 gene isolated from biopsy samples was designed. It is believed that the analysis based on the genotyping of Helicobacter pylori isolated from clinical specimens can be useful in disorders infection ${ }^{5}$. According to the results of recent studies HopQ I allele correlated significantly with an increased risk of developing ulcers stomach in Western countries is also HopQ II alleles in this population are checked frequently ${ }^{6}$. Sicinschi et al., ${ }^{1}$ on 86 children Colombian asymptomatic patients with $\mathrm{H}$. pylori by urea breath test labeled PCR and examined, the frequency of allele HopQ, VacA and CagA in samples alleles HopQ and VacA detected was $91.7 \%$ VacA s1 and $73.7 \%$ HopQ showed type 1 . HopQ type 1 allele and genotype samples with positive CagA and VacA s1 (P $<0.0001)$, respectively. Belogolova et al., ${ }^{7}$, presented a study on protein secretion system HopQ as a virulence factor associated with the type 4 strain P12 protein HopQ outer membrane of $H$. pylori cagA and answers related to displacement, including host cell cagA determination of cell morphology and cell dispersion was essential. According to the results, the researchers HopQ as a cofactor Code Type 4 plays an important role in the secretory system. In our study of 100 gastric ulcers between the presence of the gene HopQ CagA $(0.01 \mathrm{p}<)$ and also the presence of VacA s 1 Gene I HopQ (0.026p $<$ ) was a statistically significant relationship. It can be HopQ impact on virulence genes and CagA and VacA relationship between gene is developing a stomach ulcer argue. Further studies in this direction would be to identify strategies for physicians and the anti-peptic ulcer disease, gastritis and gastric cancer to improve.

\section{REFERENCES}

1. Sicinschi LA, Correa P, Bravo LE, Peek RM, Wilson KT, Loh JT, et al. Non invasive Genotyping of Helicobacter pylori cagA, vacA, and hopQ from Asymptomatic Children. Helicobacter, 2012; 17(2):96-106. doi:10.1111/ j.1523-5378.2011.00919.x 
2. Gatti LL, eSouza EKF, Leite KR, de Souza Bastos EL, Vicentini LR, da Silva LC, et al. cagA vacA alelles and babA2 genotypes of Helicobacter pylori associated with gastric disease in Brazilian adult patients. Diagn Microbiol Infect Dis, 2005; 51(4): 231-235. doi:10.1016/j.diagmicrobio.2004.11.007

3. Salama NR, Hartung ML, Müller A. Life in the human stomach: persistence strategies of the bacterial pathogen Helicobacter pylori. Nat Rev Micro, 2013; 11(6): 385-399. doi:10.1038/ nrmicro3016

4. Amieva MR, El-Omar EM. Host-bacterial interactions in Helicobacter pylori infection. Gastroenterology, 2008; 134(1): 306-323. doi:10.1053/j.gastro.2007.11.009
5. Lu H, Yamaoka Y, Graham DY. Helicobacter pylori virulence factors: facts and fantasies. Curr Opin Gastroenterol, 2005; 21(6): 653-659. doi:10.1097/01.mog.0000181711.04529.d5

6. Ohno T, Sugimoto M, Nagashima A, Ogiwara H, Vilaichone RK, Mahachai V, et al. Relationship between Helicobacter pylori hopQ genotype and clinical outcome in Asian and Western populations. J Gastroenterol Hepatol, 2009; 24(3): 462-468. doi:10.1111/j.14401746.2008.05762.x

7. Belogolova E, Bauer B, Pompaiah M, Asakura H, Brinkman V, Ertl C, et al. Helicobacter pylori outer membrane protein HopQ identified as a novel T4SS-associated virulence factor. Cell Microbiol, 2013; 15(11): 1896-1912. http:// dx.doi.org/10.1111/cmi. 12158 